\title{
Prevalence of Colorectal Polyps in Patients with Chronic Hepatitis C Virus Infection in a Multi-Ethnic Hospital Population
}

Gaby S Gil ${ }^{1}$, Silvia Fernandez ${ }^{1 *}$, Ahmed Shady ${ }^{1}$, Mohammad Saeed $^{1}$, Priyanka Yerragorla ${ }^{1}$, Laura Andreias ${ }^{1}$, Jennifer Harley ${ }^{1,2}$ an Nora V Bergasa ${ }^{1}$

${ }^{1}$ Department of Medicine, $\mathrm{H}+\mathrm{H}$, Metropolitan, PAGNY, New York, New York, and New York Medical College, Valhalla, New York, USA ${ }^{2}$ Division of Gastroenterology, H + H, Metropolitan, PAGNY, New York, New York, and New York Medical College, Valhalla, New York, USA

${ }^{\star}$ Corresponding author: Silvia Fernandez, Department of Medicine, H + H, Metropolitan, PAGNY, New York, New York, and New York Medical College, Valhalla, New York, USA

Received: July 07, 2020; Accepted: July 17, 2020; Published: July 24, 2020

\begin{abstract}
Chronic hepatitis $C$ virus infection has been associated with pre-cancerous colorectal lesions; however, there are limited data regarding the prevalence of Colorectal Polyps (CRP) in patients with Chronic Viral Hepatitis C (C-HCV). Accordingly, we conducted a retrospective study to explore this potential association by the review of an endoscopy database that included 1928 charts of adult patients who had undergone colonoscopies, and that revealed a higher prevalence of CRP in individuals with $\mathrm{C}-\mathrm{HCV}, 67.1 \%$, than in those without, $51.3 \%$, $(\mathrm{p}=0.001)$. Hyperplastic polyps comprised $56.8 \%$, and tubular adenomata $36.5 \%$ of the polyps reported. In addition, there was a preponderance of C-HCV in subjects of Hispanic ethnicity, men, and individuals who had a history of smoking and alcohol use. The most common hepatitis $\mathrm{C}$ virus genotype was $1 \mathrm{a}, 62 \%$. The prevalence of $\mathrm{CRP}$ in patients with $\mathrm{C}-\mathrm{HCV}$ was higher than in those without; however, there was no significant association between C-HCV and adenomatous polyps, which suggests that C-HCV does not predispose to colorectal cancer.
\end{abstract}

\section{Background}

Chronic hepatitis $\mathrm{C}(\mathrm{C}-\mathrm{HCV})$ is an important public health concern; thus, the impact of this viral infection on other comorbidities is of interest. Colorectal Polyps (CRP) are common gastrointestinal lesions but there are limited data regarding their prevalence in patients with C-HCV.

As C-HCV has been associated with malignancy [1-6], we hypothesized that CRPs would be more common in patients with C-HCV than in those without. Accordingly, the aim of this study was to explore that prevalence of CRPs, which can develop into colorectal cancer, in patients with C-HCV who had had a screening colonoscopy at $\mathrm{H}+\mathrm{H}$, Metropolitan, a community hospital that serves the multiethnic population of East Harlem.

\section{Methods}

Data from records of 1,928 patients who had a complete colonoscopy report in the database from the Division of Gastroenterology and Hepatobiliary Diseases from January 1 $1^{\text {st }}, 2011$ to December $31^{\text {st }}, 2015$ were retrospectively reviewed. The study group was comprised of adults with C-HCV, defined as detected HCV RNA in serum, who had undergone a complete screening or diagnostic colonoscopy after a good bowel preparation confirmed during the procedure. The control group was composed of patients who underwent a screening colonoscopy and who did not have antibodies for the hepatitis $\mathrm{C}$ virus.
In addition, we examined some of the characteristics of the population such as ethnicity, gender, and toxic habits to explore potential associations with $\mathrm{C}-\mathrm{HCV}$. Correlations between categorical variables were analyzed by the use of Chi-square test, and t-test for continuous variables between groups. Bivariate analysis was applied to identify any links between the exposure variable and the outcome variable. A p value of $<0.05$ was considered significant. Statistical analysis was performed with SPSS 24 software. This study was approved by the Biomedical Research Alliance of New York (BRANY).

\section{Results}

Among 1928 individuals with complete colonoscopies, we identified 960 patients who had been tested for hepatitis C virus infection, of whom 159 had C-HCV. Gender was the only factor that was significantly different in the C-HCV group versus the control, with the majority, $65 \%$, being men $(\mathrm{p}<0.001)$ (Figure 1$)$. Fifty-three percent of the patients with C-HCV self-identified as Hispanics. In addition, $34 \%$ and $38 \%$ of the patients in the HCV infected group reported an active/former smoker status or admitted being at least a social alcohol consumer, respectively.

There was a higher prevalence of CRP in individuals with C-CHV, 67.1\%, in comparison with those without, 51.3\% ( $\mathrm{p}=0.001)$. Hyperplastic polyps comprised $56.8 \%$ of the polyps and tubular adenomata, 36\%. Hyperplastic was the histopathologic predominant type in patients with $\mathrm{C}-\mathrm{HCV}, 75 \%$, and in the control group, $69 \%$; 


\section{CHARACTERISTICS OF STUDIED PATIENTS IN WHOM POLYPS WERE FOUND}

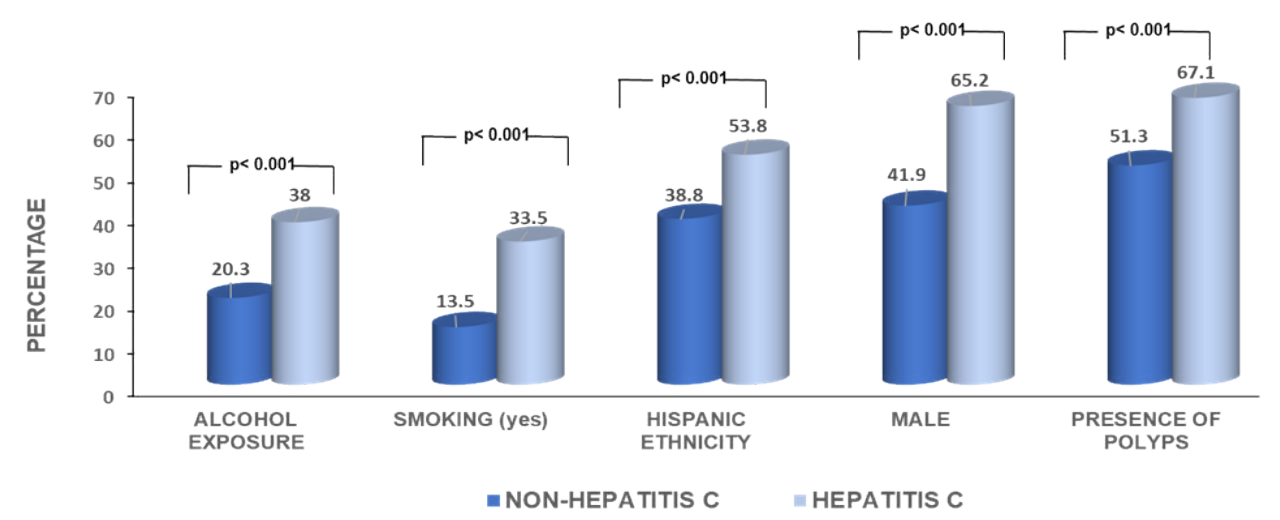

Figure 1: Complete colonoscopies among 1928 individuals.

DISTRIBUTION OF COLORECTAL POLYPS BY HISTOPATHOLOGY

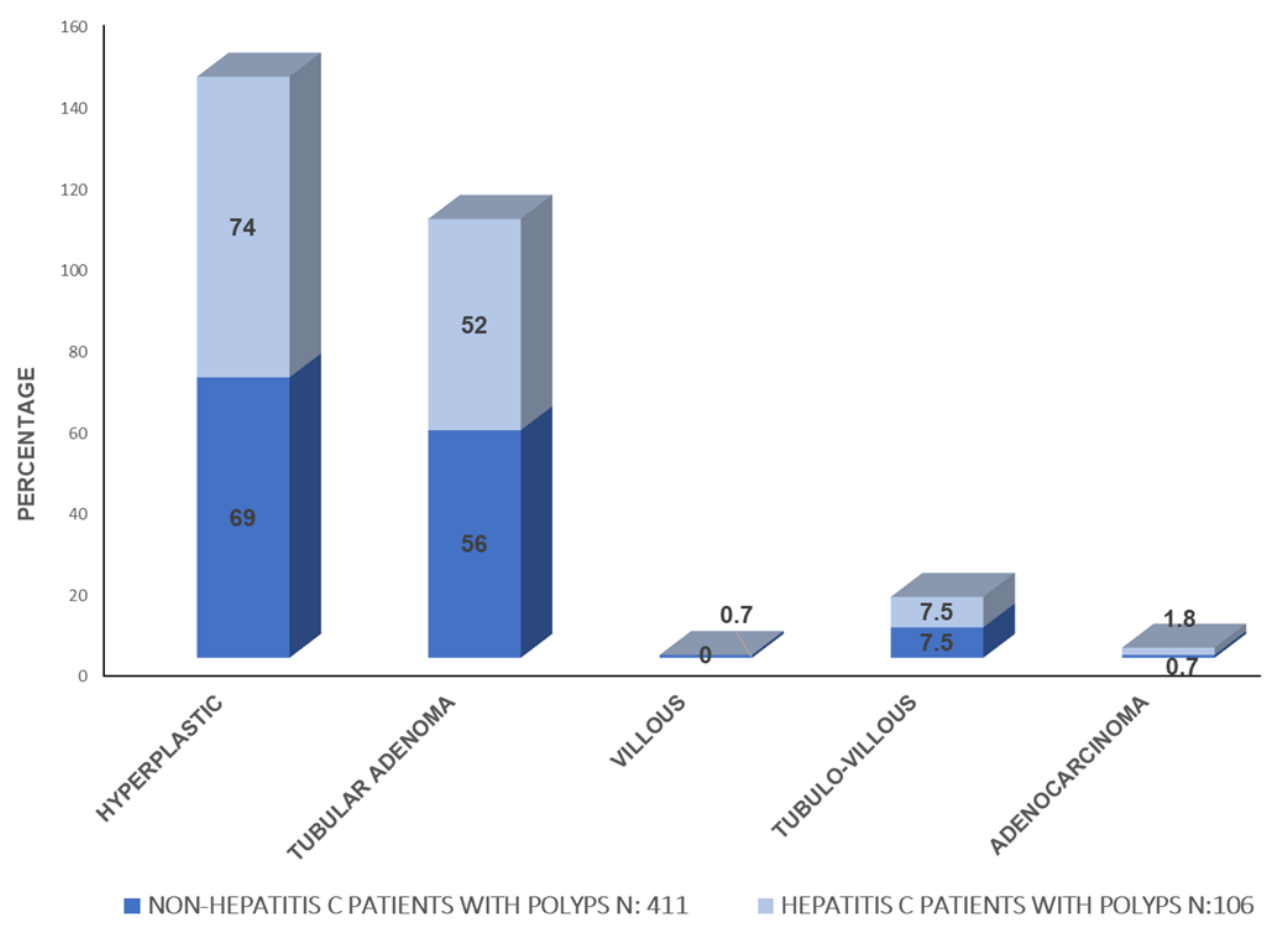

Figure 2: Distribution of colorectal polyps by histopathology.

however, this difference was statistically significant $(\mathrm{p}<0.005)$ (Figure 2). Most patients with $\mathrm{C}-\mathrm{HCV}, 62 \%$, had genotype $1 \mathrm{a}$.

\section{Discussion}

In this study, the prevalence of CRP in patients with $\mathrm{C}-\mathrm{HCV}$ was higher than in those without. The predominant histology of the CRP was hyperplastic. There was a preponderance of C-HCV in men, in smokers, in those who used alcohol, and in subjects of Hispanic ethnicity, consistent with the ethnicity of the majority of patients attended at Metropolitan Hospital.

Colorectal cancer has been associated with C-HCV [7]; however, we excluded from this study patients with history or active colorectal cancer. CRP were more prevalent in the $\mathrm{C}-\mathrm{HCV}$ group of patients with a predominance of hyperplastic histology [8-44]. Hyperplastic Polyps (HP) are included in the serrated polyp classification [45-50], which encompasses Sessile Serrated Lesions (SSL) and Traditional Serrated Adenomas (TSA). SSL and TSA have been associated with malignancy; however, none of the polyps found in this study had a serrated histology.

The HCV virus itself may stimulate cell proliferation, inflammation and apoptosis increasing the risk of polyp formation [26-29]. The hepatitis $C$ virus has been found in colonic cells such as lymphocytes, macrophages, monocytes [6,8-15]. As polyps possibly result from a defective/enhanced repair process after a mucosal injury [26], and 
mutations seem to be the molecular events leading to polyp's formation, we may speculate that the presence of viral RNA in the colonic mucosal cells may also cause some disruption in this process [51-78].

$53 \%$ and $38 \%$ of the patients with $\mathrm{C}-\mathrm{HCV}$ reported active or former smoker status or admitted being at least a social alcohol consumer. Cigarette smoking has been associated with an increased in progression of liver disease in patients with $\mathrm{C}-\mathrm{HCV}$ [20]. In this study, data were recorded as current smokers and former smokers while the Nonsmokers (NS) were those who stated have never smoked. This group was comprised of $34 \%$ of the patients with C-HCV versus $14 \%$ in the control group, a difference that was statistically significant $(\mathrm{p}<0.001)$. This finding is consistent with a prior report $[18,19]$.

The association between alcohol use disorder and C-HCV has been described $[23,24]$. Alcohol use was reported more frequently by the patients with C-HCV, $38 \%$ versus $20 \%$ in the control group ( $\mathrm{p}<0.001)$.

In summary, there was a preponderance of $\mathrm{C}-\mathrm{HCV}$, most commonly genotype 1a, among subjects of Hispanic ethnicity, men, and individuals who had a history of smoking and alcohol use. Hepatitis $\mathrm{C}$ virus infection is not associated with adenomatous colonic polyps, and thus, it does not predispose by itself to colorectal cancer.

\section{References}

1. Crovatto M, Pozzato G, Zorat F, Pussini E, Nascimben F, et al. (2000) Peripheral blood neutrophils from hepatitis $\mathrm{C}$ virus infected patients are replication sites of the virus. Haematologica 85: 356-361. [crossref]

2. Sansonno D, Lauletta G, Montrone M, Grandaliano G, Schena FP, et al. (2005) Hepatitis C virus RNA and core protein in kidney glomerular and tubular structures isolated with laser capture microdissection. Clin. Exp. Immunol 140: 498-506. [crossref]

3. Kurokawa M, Hidaka T, Sasaki H, Nishikata I, Morishita K, et al. (2003) Analysis of Hepatitis C Virus (HCV) RNA in the lesions of lichen planus in patients with chronic hepatitis C: detection of anti-genomic- as well as genomic-strand HCV RNAs in lichen planus lesions. J. Dermatol. Sci 32: 65-70. [crossref]

4. Carrozzo M, Quadri R, Latorre P, Pentenero M, Paganin S, et al. (2002) Molecular evidence that the hepatitis $\mathrm{C}$ virus replicates in the oral mucosa. J. Hepatol 37: 364 369. [crossref]

5. Toussirot E, Le Huédé G, Mougin C, Balblanc JC, Bettinger D, et al. (2002) Presence of hepatitis C virus RNA in the salivary glands of patients with Sjögren's syndrome and hepatitis C virus infection. J. Rheumatol 29: 2382-2385. [crossref]

6. Yan FM, Chen AS, Hao F, Zhao XP, Gu CH, et al. (2000) Hepatitis C virus may infect extrahepatic tissues in patients with hepatitis C. World J. Gastroenterol 6: 805-811. [crossref]

7. Fu-Hsiung S, Mekky MA, Khalil NK, Mohamed WA, El-Feky MA, et al. (2011) The association between chronic hepatitis $\mathrm{C}$ infection and colon cancer: a nationwide case control study. BMC Cancer 11: 495. [crossref]

8. Hetta HF, Mekky MA, Khalil NK, Mohamed WA, El-Feky MA, et al. (2016) Extrahepatic infection of hepatitis $C$ virus in the colon tissue and its relationship with hepatitis C virus pathogenesis. Journal of Medical Microbiology 65: 703-712. [crossref]

9. Castillo I, Rodríguez-Iñigo E, Bartolom_e J, de Lucas S, Ortíz-Movilla N, et al. (2005) Hepatitis $\mathrm{C}$ virus replicates in peripheral blood mononuclear cells of patients with occult hepatitis C virus infection. Gut 54: 682-685. [crossref]

10. Chang TT, Young KC, Yang YJ, Lei HY, Wu HL (1996) Hepatitis C virus RNA in peripheral blood mononuclear cells: comparing acute and chronic hepatitis $\mathrm{C}$ virus infection. Hepatology 23: 977-981. [crossref]

11. Manzin A, Candela M, Paolucci S, Caniglia ML, Gabrielli A, Clementi M (1994) Presence of hepatitis $\mathrm{C}$ virus (HCV) genomic RNA and viral replicative intermediates in bone marrow and peripheral blood mononuclear cells from HCV-infected patients. Clin Diagn Lab Immunol 1: 160-163. [crossref]
12. Saleh MG, Tibbs CJ, Koskinas J, Pereira LM, Bomford AB, et al. (1994) Hepatic and extrahepatic hepatitis $\mathrm{C}$ virus replication in relation to response to interferon therapy. Hepatology 20: 1399-1404.

13. Wang JT, Sheu JC, Lin JT, Wang TH, Chen DS (1992) Detection of replicative form of hepatitis C virus RNA in peripheral blood mononuclear cells. J Infect Dis 166: 1167-1169. [crossref]

14. Blackard JT, Kong L, Huber AK, Tomer Y (2013) Hepatitis C virus infection of a thyroid cell line: implications for pathogenesis of hepatitis $\mathrm{C}$ virus and thyroiditis. Thyroid 23: 863-870. [crossref]

15. Fletcher NF, Wilson GK, Murray J, Hu K, Lewis A, et al. (2012) Hepatitis C virus infects the endothelial cells of the blood brain barrier. Gastroenterology 142: 634-643. [crossref]

16. https://furmancenter.org/neighborhoods/view/east-harlem

17. Harrell, Trenz RC, Scherer M, Pacek LR, Latimer WW, et al. (2020) Cigarette smoking, illicit drug use, and routes of administration among heroin and cocaine users. Addict Behav 37: 678-681. [crossref]

18. Kim RS, Weinberger AH, Chander G, Sulkowski MS, Norton B, et al. (2018) Cigarette Smoking in Persons Living with Hepatitis C: The National Health and Nutrition Examination Survey (NHANES), 1999-2014. Am J Med 131: 669:675. [crossref]

19. Chew KW, Bhattacharya D, McGinnis KA, Horwich TB, Tseng CH, et al. (2015) Short communication: coronary heart disease risk by Framingham risk score in hepatitis $\mathrm{C}$ and HIV/Hepatitis C-Coinfected persons. AIDS ResHumRetroviruses 31: 718-722. [crossref]

20. HCV Guidance: Recommendations for Testing, Managing, and Treating Hepatitis C. 2014-2020 AASLD and IDSA v2020.4. www.HCVGuidance.org on May 25, 2020.

21. Shi et al. (2010) Smoking and Pain. Pathophysiology and Clinical Implications. Anesthesiology 113: 977-979

22. Weinberger AH, Platt J, Esan H, Galea S, Erlich D, et al. (2017) Cigarette smoking is associated with increased risk of substance use disorder relapse: A nationally: representative, prospective longitudinal investigation. Journal of Clinical Psychiatry 78: e152-e160. [crossref]

23. Lieber CS. (2001) Alcohol and Hepatitis C. Alcohol Research \& Health 25: 245-254.

24. Rosman AS, Waraich A, Galvin K, Casiano J, Paronetto F, et al. (1996) Alcoholism Is Associated With Hepatitis C but Not Hepatitis B in an Urban Population. Am J Gastroenterol 91: 498-505. [crossref]

25. "Excessive Alcohol Use". www.cdc.gov/chronicdisease. n.d. Accessed on May 25, 2020

26. Lemon SM, McGivern DR (2012) Is Hepatitis C Virus Carcinogenic? Gastroenterology 142: 1274-1278. [crossref]

27. Hurtado-Cordovi J, Davis-Yadley AH, Lipka S, Vardaros M, Shen H (2016) Association between chronic hepatitis $\mathrm{C}$ and hepatitis C/HIV co-infection and the development of colorectal adenomas. J Gastrointest Oncol 7: 609-614. [crossref]

28. Rustagi T, Zarookian EI, Qasba O, Diez LF (2014) Chronic hepatitis C as a risk factor for colorectal adenoma. Int J Colorectal Dis 29: 75. [crossref]

29. Mitchell JK, Midkiff BR, Israelow B, Evans MJ, Lanford RE, et al. (2017) Hepatitis C virus indirectly disrupts DNA damage-induced $\mathrm{p} 53$ responses by activating protein kinase R. mBio 8: e00121-17. [crossref]

30. Hepatitis C online. HCV Epidemiology in the United States. Accessed on May 23, 2020

31. Butterfield MI, Bosworth HB, Meador KG, Stechuchak KM, Essock SM, et al. (2003) Gender Differences in Hepatitis C Infection and Risks Among Persons With Severe Mental Illness. Psychiatric Services 54: 848-853. [crossref]

32. Midgley L, et al. (2017) Acute hepatitis C infection in lower risk MSM: an evolving picture. British HIV Association conference, abstract O24, Liverpool.

33. Dodge JL, Terrault NA (2014) Sexual transmission of hepatitis C: A rare event among heterosexual couples. J Coagul Disord 4: 38-39. [crossref]

34. CF Kelley, Kraft CS, de Man TJ, Duphare C, Lee HW, et al. (2016) The rectal mucosa and condomless receptive anal intercourse in HIV-negative MSM: implications for HIV transmission and prevention 10: 996-1007. [crossref] 
35. Harawa NT, Williams JK, Ramamurthi HC, Manago C, Avina S, et al. (2008) Sexual Behavior, Sexual Identity, and Substance Abuse Among Low-Income Bisexual and Non-Gay-Identifying African American Men Who Have Sex with Men. Arch Sex Behav 37: 748-762. [crossref]

36. Levran O, Yuferov V, Kreek MJ (2012) The genetics of the opioid system and specific drug addictions. Hum Genet 131: 823-842. [crossref]

37. Bart G, Kreek MJ, Ott J, LaForge KS, Proudnikov D, et al. (2005) Increased attributable risk related to a functional mu-opioid receptor gene polymorphism in association with alcohol dependence in central Sweden. Neuropsychopharmacology 30: 417-422. [crossref]

38. Deb I, Chakraborty J, Gangopadhyay PK, Choudhury SR, Das S (2010) Singlenucleotide polymorphism (A118G) in exon 1 of OPRM1 gene causes alteration in downstream signaling by mu-opioid receptor and may contribute to the genetic risk for addiction. J Neurochem 112: 486-496. [crossref]

39. Kim SG, Kim CM, Kang DH, Kim YJ, Byun WT, et al. (2004) Association of functional opioid receptor genotypes with alcohol dependence in Koreans. Alcohol Clin Exp Res 28: 986-990. [crossref]

40. Nishizawa D, Han W, Hasegawa J, Ishida T, Numata Y, et al. (2006) Association of muopioid receptor gene polymorphism A118G with alcohol dependence in a Japanese population. Neuropsychobiology 53: 137-141. [crossref]

41. Rommelspacher H, Smolka M, Schmidt LG, Samochowiec J, Hoehe MR (2001) Genetic analysis of the muopioid receptor in alcohol-dependent individuals. Alcohol 24: 129-135. [crossref]

42. Spooner C, Hetherington K (2004) Social determinants of drug use. Technical Report Number 228. ISBN: 073342244 6. National Drug and Alcohol Research Centre, University of New South Wales, Sydney.

43. Fu-Hsiung S, et al. (2011) The association between chronic hepatitis $\mathrm{C}$ infection and colon cancer: a nationwide case control study. BMC Cancer 11: 495.

44. Kamiza, Su FH, Wang WC, Sung FC, Chang SN, et al. (2016) Chronic hepatitis infection is associated with extrahepatic cancer development: a nationwide population-based study in Taiwan. BMC Cancer 16: 861. [crossref]

45. Singh R, Zorrón Cheng Tao Pu L, Koay D, Burt A (2016) Sessile serrated adenoma/ polyps: Where are we at in 2016? World J Gastroenterol 22: 7754-7759. [crossref]

46. Crockett SD, Nagtegaal ID (2019) Terminology, Molecular Features, Epidemiology, and Management of Serrated Colorectal Neoplasia. Gastroenterology 157: 949-966. [crossref]

47. Ensari A, Bilezikci B, Carneiro F, Doğusoy GB, Driessen A, et al. (2012) Serrated polyps of the colon: how reproducible is their classification? Virchows Arch 461: 495504. [crossref]

48. Rau TT, Agaimy A, Gehoff A, Geppert C, Jung K, et al. (2014) Defined morphological criteria allow reliable diagnosis of colorectal serrated polyps and predict polyp genetics. Virchows Arch 464: 663-672. [crossref]

49. World Health Organization (2019) Classification of Tumors of the Digestive Tract. Lyon: IARC Press.

50. O’Brien MJ, Yang S, Clebanoff JL, Mulcahy E, Farraye FA, et al. (2004) Hyperplastic (serrated) polyps of the colorectum: relationship of $\mathrm{CpG}$ island methylator phenotype and K-ras mutation to location and histologic subtype. Am J Surg Pathol 28: 423-434. [crossref]

51. Kim CW, Chang K-M (2013) Hepatitis C virus: virology and life cycle. Clinical and Molecular Hepatology Review 19: 17-25. [crossref]

52. Morimoto LM, Newcomb PA, Ulrich CM, Bostick RM, Lais CJ, et al. (2002) Risk Factors for Hyperplastic and Adenomatous Polyps: Evidence for Malignant Potential? Cancer Epidemiology, Biomarkers \& Prevention 11: 1012-1018. [crossref]

53. Russelli G, Pizzillo P, Iannolo G, Barbera F, Tuzzolino F, et al. (2017) HCV replication in gastrointestinal mucosa: Potential extra-hepatic viral reservoir and possible role in HCV infection recurrence after liver transplantation. PLoS ONE 12: e0181683. [crossref]

54. Bare P (2009) Hepatitis C virus and peripheral blood mononuclear cell reservoirs Patricia Bare. World J Hepatol 1: 67-71. [crossref]

55. Bare P, Massud I, Parodi C, Belmonte L, Garcia G, Nebel MC, et al. (2005) Continuous release of Hepatitis C Virus (HCV) by peripheral blood mononuclear cells and B-lymphoblastoid cell-line cultures derived from HCV-infected patients. J Gen Virol 86: 1717-1727. [crossref]
56. Caussin-Schwemling C, Schmitt C, Stoll-Keller F (2001) Study of the infection of human blood derived monocyte/macrophages with hepatitis $\mathrm{C}$ virus in vitro. $\mathrm{J} \mathrm{Med}$ Virol 65: 14-22. [crossref]

57. Goutagny N, Fatmi A, De Ledinghen V, Penin F, Couzigou P, et al. (2003) Evidence of viral replication in circulating dendritic cells during hepatitis $\mathrm{C}$ virus infection. J Infect Dis 187: 1951-1958. [crossref]

58. Haruna Y, Kanda T, Honda M, Takao T, Hayashi N (2001) Detection of hepatitis C virus in the bile and bile duct epithelial cells of hepatitis $\mathrm{C}$ virus-infected patients. Hepatology 33: 977-980. [crossref]

59. Januszkiewicz-Lewandowska D, Wysocki J, Pernak M, Nowicka K, Zawada M, et al. (2007) Presence of hepatitis C virus (HCV)-RNA in peripheral blood mononuclear cells in HCV serum negative patients during interferon and ribavirin therapy. Jpn J Infect Dis 60: 29-32. [crossref]

60. Moradpour D, Penin F, Rice CM (2007) Replication of hepatitis C virus. Nat Rev Microbiol 5: 453-463. [crossref]

61. Sansonno D, Lauletta G, Montrone M, Tucci FA, Nisi L, et al. (2006) Virological analysis and phenotypic characterization of peripheral blood lymphocytes of hepatitis C virus-infected patients with and without mixed cryoglobulinaemia. Clin Exp Immunol 143: 288-296. [crossref]

62. McGivern DR, Lemon SM (2011) Virus-specific mechanisms of carcinogenesis in hepatitis C virus associated liver cancer. Oncogene 30: 1969-1983. [crossref]

63. Otori K, Oda Y, Sugiyama K, Hasebe T, Mukai K, et al. (1997) High frequency of K-ras mutation in human colorectal hyperplastic polyps. Gut 40: 660-663. [crossref]

64. Zahm SH, Cocco P, Blair A (1991) Tobacco smoking as a risk factor for colon polyps. Am. J. Public Health 81: 846-849. [crossref]

65. Kearney J, Giovannucci E, Rimm EB, Stampfer M, Colditz GA, et al. (1995) Diet, alcohol, and smoking and the occurrence of hyperplastic polyps of the colon and rectum (United States). Cancer Causes Control, 6: 45-56. [crossref]

66. Martinez ME, McPherson RS, Levin B, Glober GA (1997) A case control study of dietary intake and other lifestyle risk factors for hyperplastic polyps. Gastroenterology 113: 423-429. [crossref]

67. Gordon SC, Trudeau S, Li J, Zhou Y, Rupp LB, et al. (2019) Race, Age, and Geography Impact Hepatitis C Genotype Distribution in the United States. J Clin Gastroenterol 53: 40-50. [crossref]

68. Iloeje UH, Yang HI, Jen CL, Su J, Wang LY, et al. (2010) Risk of pancreatic cancer in chronic hepatitis B virus infection: data from the REVEAL-HBV cohort study. Liver Int 30: 423-429. [crossref]

69. Fwu CW, Chien YC, Nelson KE, Kirk GD, You SL, et al. (2010) Mortality after chronic hepatitis B virus infection: a linkage study involving 2 million parous women from Taiwan. J Infect Dis 201: 1016-1023. [crossref]

70. Engels EA, Cho ER, Jee SH (2010) Hepatitis B virus infection and risk of non-Hodgkin lymphoma in South Korea: a cohort study. Lancet Oncol 11: 827-834. [crossref]

71. Fwu CW, Chien YC, You SL, Nelson KE, Kirk GD, et al. (2011) Hepatitis B virus infection and risk of intrahepatic cholangiocarcinoma and non-Hodgkin lymphoma: a cohort study of parous women in Taiwan. Hepatol Baltim Md 53: 1217-1225. [crossref]

72. Ulcickas Yood M, Quesenberry CP, Guo D, Caldwell C, Wells K, Shan J, et al. (2007) Incidence of non-Hodgkin's lymphoma among individuals with chronic hepatitis $\mathrm{B}$ virus infection. Hepatol Baltim Md. 46: 107-112.

73. Amin J, Dore GJ, O'Connell DL, Bartlett M, Tracey E, et al. (2006) Cancer incidence in people with hepatitis $\mathrm{B}$ or $\mathrm{C}$ infection: a large community based linkage study. J Hepatol 45: 197-203. [crossref]

74. Manos MM, Shvachko VA, Murphy RC, Arduino JM, Shire NJ (2012) Distribution of hepatitis $\mathrm{C}$ virus genotypes in a diverse US integrated health care population. $J$ Med Virol 84: 1744-1750. [crossref]

75. Xie Y, Garza G, Dong J (2016) Hepatitis C virus genotype and subtype distribution in patient specimens tested at the University of Texas Medical Branch, Galveston, Between January 2011 and November 2014. Lab Med 47: 112-118. [crossref]

76. G Hoff, MH Vatn, Larsen S. Relationship between Tobacco Smoking and Colorectal Polyps. Scandinavian Journal of Gastroenterology 22: 1987. [crossref] 
Silvia Fernandez (2020) Prevalence of Colorectal Polyps in Patients with Chronic Hepatitis C Virus Infection in a Multi-Ethnic Hospital Population

77. Narayan S, Roy D (2003) Role of APC and DNA mismatch repair genes in the development of colorectal cancers. Molecular Cancer 2: 41. [crossref]
78. Meseeha M, Attia M (2020) Colon Polyps. In: StatPearls [Internet]. Treasure Island (FL): StatPearls Publishing. [crossref]

\section{Citation:}

Gaby S Gil, Silvia Fernandez, Ahmed Shady, Mohammad Saeed, Priyanka Yerragorla, Laura Andreias, Jennifer Harley and Nora V Bergasa (2020) Prevalence of Colorectal Polyps in Patients with Chronic Hepatitis C Virus Infection in a Multi-Ethnic Hospital Population. Adv Gastroenterol Hepatol Endoscopy Volume 2(1): 1-5. 